\title{
IL-17 as an important effector cytokine in a mouse model for S.typhimurium sepsis
}

\author{
Andrea Schroll", Manfred Nairz, Igor Theurl, Günther Weiss \\ From 7th European Workshop on Immune-Mediated Inflammatory Diseases \\ Noordwijk aan Zee, the Netherlands. 28-30 November 2012
}

\section{Background}

Naïve $\mathrm{CD} 4^{+}$helper $\mathrm{T}$ cells differentiate after TCR activation into the 3 characterizing cytokine-secreting effector cells: $\mathrm{T}_{\mathrm{H}^{-}}, \mathrm{T}_{\mathrm{H}^{-}}$, and $\mathrm{T}_{\mathrm{H}^{-}}-17$. The $\mathrm{T}_{\mathrm{H}^{-}}$. lineage is characterized by IL-17 production and is induced by IL-23, IL-6 and TGF-ß.

The role of iron in IL-17-mediated immune functions however, has not been elucidated thus far. Herein, we investigated the involvement of IL-17 in immune response against S. typhimurium.

\section{Materials}

$40 \mathrm{C} 57 \mathrm{bl} / 6$ mice were divided into 10 groups. 20 mice received an iron enriched diet, whereas the others were kept on standard diet. After 3 weeks 16 mice of the iron group and 16 mice of the non-iron group were infected 500 CFU (colony forming units) Salmonella typhimurium by intraperitoneal injection. In addition, 8 mice fed the iron diet and 8 mice of standard diet mice received $100 \mu \mathrm{g}$ of a blocking IL-17 monoclonal antibody 2 hours prior to infection by intraperitoneal injection. Mice were either killed $6 \mathrm{~h}$ or $24 \mathrm{~h}$ post infection and the bacterial load in liver and spleen was quantified by plating organ homogenates.

\section{Results}

IL-17 blockade resulted in an increased weight loss in iron overloaded and control mice. Additionally, spleen weight was upregulated $24 \mathrm{~h}$ post infection. Intriguingly, we could observe increased CFU in blood, liver and spleen in IL-17 $\mathrm{mAb}$ treated $6 \mathrm{~h}$ and $24 \mathrm{~h}$ post infection.

\section{Conclusion}

We could show the importance of IL-17 in S.typhimurium infection and the combination of iron overload and IL-17

\footnotetext{
Univ. Clinic, Dept. of General Internal Medicine, Clinical Immunology and Infectious Diseases, Innsbruck, Austria
}

(c) 2012 Schroll et al; licensee BioMed Central Ltd. This is an Open Access article distributed under the terms of the Creative Commons Attribution License (http://creativecommons.org/licenses/by/2.0), which permits unrestricted use, distribution, and reproduction in any medium, provided the original work is properly cited. blockade aggravates the severity of S.typhimurium infection. Thus, our data suggests that iron might play a crucial role in Th17 immune response.

Published: 28 November 2012

doi:10.1186/1479-5876-10-S3-P14

Cite this article as: Schroll et al:: IL-17 as an important effector cytokine in a mouse model for S.typhimurium sepsis. Journal of Translational Medicine 2012 10(Suppl 3):P14.
Submit your next manuscript to BioMed Central and take full advantage of:

- Convenient online submission

- Thorough peer review

- No space constraints or color figure charges

- Immediate publication on acceptance

- Inclusion in PubMed, CAS, Scopus and Google Scholar

- Research which is freely available for redistribution 